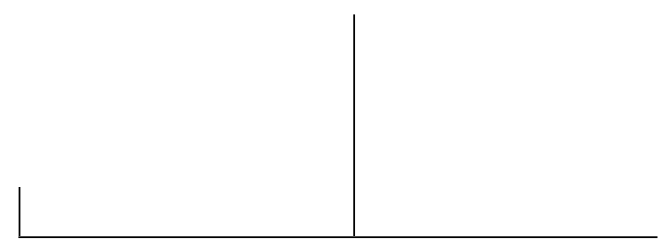

Rev. Latinoam. Psicopat. Fund., São Paulo, v. 15, n. 4, 926-928, dezembro 2012

La voix sur le divan - Musique sacrée, opéra, techno

Jean-Michel Vives

Paris: Aubier, 2012, 224 págs.

\title{
Voz e música no divã de Jean-Michel Vives - ou O canto surdo de um analista
}

Renata Mattos

Lá onde isso era, invoque! Jean-Michel Vives

Cinquenta anos após a conceituação explícita no Seminário $A$ angústia da invenção lacaniana sobre o objeto $a$, tendo sido aí incluídos o olhar e a voz na lista freudiana de objetos pulsionais, eis que surge um livro decisivo sobre o objeto voz e sobre a rica e, precisamos agora admitir, necessária articulação entre psicanálise e música. Com A voz sobre o divã - Música sacra, ópera, techno, de Jean-Michel Vives, se restavam quaisquer dúvidas sobre a importância e a função para a psicanálise de uma reflexão sobre a música, estas são completamente desfeitas e o que resta, então, é o desejo em dizer sim à provocação invocante que o autor nos faz de mais ouvir ou de ouvir mais-além.

Ainda que possamos encontrar livros e artigos sobre tal articulação, especialmente com Michel Poizat e Alain Didier-Weill - que aqui nos brinda com um belo e original posfácio -, nenhum deles 
se apresenta com tamanha amplitude temática, clareza conceitual e pertinência clínica. Vives percorre, com leveza e audácia, o universo da música, entrelaçando-o com questões preeminentemente analíticas. Escutamos um percurso de vivas elaborações, indo desde a musicalidade da voz materna, passando pela música clássica e operística, pela musicalidade ritualística do schofar, pelo feminino musical e o gozo invocante/escópico, até chegar, de forma surpreendente, ao extremo contemporâneo do techno e do timbre. Compositores como Monteverdi, Offenbach, Berg, Wagner, Mozart, e cantores como Farinelli e Moreschi, ambos castrati, e Maria Callas dialogam com Vives sem que, com isso, ele os interprete. O que se almeja é fazer a música "falar" por si, se fazer ouvir.

Tal trajetória de grande fôlego sobre o campo musical - do qual Vives serviu-se, na prática, como cantor e diretor de ópera - se depura na primeira definição genuinamente psicanalítica sobre música. Para além da materialidade e da organização dos sons, Vives a afirma como "a extensão instrumentalizada da voz" que visa "um mais além ou um aquém da linguagem, restando ligada a essa última" (Vives, 2012, p. 33). O fio que fundamenta tal viagem analítico-musical é a voz e seus desdobramentos na psicanálise e a invenção conceitual de Vives: o ponto surdo.

Há anos presente na gramática vivesiana, este ponto ganha prolíferos avanços que levam o autor a efetuar quase uma "revisão" do estatuto do circuito da pulsão invocante, correlata à voz. Anteriormente já por ele definido a partir da lógica freudiana em três tempos pulsionais, tal circuito é demarcado com ainda maior clareza por sua intrínseca dimensão do chamamento, declinando-se em "ser ouvido/chamar", "ouvir/ser chamado" e "se fazer ouvir/se fazer chamar". E isso implica a hipótese de que o sujeito deverá se tornar ele próprio invocante, sustentando que há um Outro não surdo capaz de escutá-lo (Ibid., p. 35-36).

O que interessa a Vives são os efeitos de ressonância da voz do Outro no sujeito e suas consequências éticas, bem como a dimensão de gozo que a trama simbólica-real-imaginária musical põe em cena. Mais que isso, o pensamento de Vives, nas ondas que ele propaga, leva a uma questão crucial sobre o desejo do analista: não haveria nesse desejo um ponto surdo que faz com que cada analista venha a se autorizar como uma função para um sujeito em análise? E não seria o ponto surdo de Vives, de fato, ponto surdo que o faz se destacar no campo analítico como psicanalista e autor singular, com voz que se faz ouvir?

Vives estabelece, assim, um canto peculiar, nos convocando a sustentar a dimensão de despertar para o sujeito. Canto surdo que se apresenta como advertido, portando um inaudito. Canto surdo que reafirma a possibilidade de que um Outro não surdo possa comparecer na análise, recolocando em causa o desejo e invocando uma saída nova por improviso a dois, estando analisante e analista em 
posições diferentes. Canto que faz de nós, leitores-ouvintes, não-surdos para escutá-lo e, a partir daí, improvisarmos.

\section{Referência}

Vives, J.-M (2012). La voix sur le divan - Musique sacrée, opéra, techno. Paris: Aubier.

\section{Renata Mattos}

Psicanalista, doutora em Pesquisa e Clínica em Psicanálise pela Universidade do Estado do Rio de Janeiro - UERJ (Rio de Janeiro, RJ, Br), com estágio Capes/PDEE na Université de Nice Sophie-Antipolis (França). Investiga a articulação entre psicanálise e música a partir da constituição do sujeito e do objeto voz, contando com publicações sobre este tema.

Rua Tamoios, 200 - São Francisco

24360-380 Niterói, RJ, Br

Fone: 552121700804

e-mail: renatamattos.rm@gmail.com

Rev. Latinoam. Psicopat. Fund., São Paulo, v. 15, n. 4, p. 926-928, dezembro 2012 